\title{
Extraction of Stigmasterol and $\beta$-Sitosterol from the leaves of Acanthus montanus and their contractile activity on uterine muscles of non-pregnant female albino rats
}

\author{
E. M. Jonathan ${ }^{1 *}$ and F. E. Okieimen ${ }^{1}$ \\ ${ }^{1}$ Department of Chemistry, University of Benin, Benin City, Nigeria. \\ *Corresponding author's email: eribemary@yahoo.com \\ Received 11 April 2020; accepted 10 May 2020, published online 30 October 2020
}

\section{Abstract}

Acanthus montanus is an important medicinal plant belonging to the family Acanthaceae. It is a plant with several phytoconstituents which accounts for its tradopharmacological uses such as treatment of pain, female infertility and spontaneous abortion with dosage schedule depending on the ailment. The present study was aimed at identifying and characterizing some of the active principles from leaves of the plant.

Keywords: Acanthus montanus; Stigmasterol; $\beta$-sitosterol; contractile activity; uterine contraction; non-pregnant rat.

\section{Introduction}

Acanthus montanus is a thinly branched perennial with basal clusters of oblong to lance-shaped glossy, dark green leaves reaching up to 12 inches $(30 \mathrm{~cm})$ long. The leaves have silver marks and wavy margins. It reaches up to 6 feet $(1.8 \mathrm{~m})$ tall and about 24 inches $(61 \mathrm{~cm})$ wide. It's a shrub widespread in Africa, the Balkans, Romania, Greece and Eastern Mediterranean [1]. In Nigeria, it is locally called cogwudurunwashishi' (Ibo), ebe-igbe'(Akoko-Edo) karinkan' (Yoruba) and odi-igban (Ijaws) [2]. Sterols, predominantly sitosterol, stigmasterol and campesterol are present in practically all the plant species. Their synthetic derivatives are known as statins, which are used as cholesterol lowering drugs [3]. Sterols are the first choice of potential natural preventive dietary products [4] and Stigmasterol and $\beta$-sitosterol are two phytosterols, structurally similar to cholesterol and are well spread in plants, fungi and animals [5]. These are secondary metabolites and are used as health promoting constituents of natural foods [6]. The sterol glucoside contains the hydrophilic glucose moiety which inhibits the entry of cholesterol into the esterification of cholesterol [7-8]. European foods and safety authority recommends consuming about 1.5 to $2-4 \mathrm{~g} /$ day of phytosterol in order to reduce blood pressure [8]. In addition, the US Food and Drug Administration has approved the role of foods containing phytosterol esters, and a low saturated fat and cholesterol diet in reducing the risk of heart attack [9-10]. $\beta$-sitosterol- $\beta$-D glucoside has been proposed as a useful candidate for the development of new drugs to treat endotoxemia and inflammation accompanied by the overproduction of nitric oxide. This compound reduces nitric oxide production from lipopolysaccharide-induced RAW 264.7 cells. In addition, it strongly inhibits the interleukin 6 activities of stimulated macrophages [11-12].

\section{Materials and Methods}

\section{General Experimental Procedure}

Nuclea magnetic Resonance (NMR) analysis was recorded on a Bruker Avance 3 spectrometer at $400 \mathrm{MHz}\left({ }^{1} \mathrm{H}\right), 376 \mathrm{MHz}\left({ }^{19} \mathrm{~F}\right)$ and $101 \mathrm{MHz}\left({ }^{13} \mathrm{C}\right)$. All spectra were measured in $\mathrm{CDCl}_{3}$ to which chemical shifts in parts per million (ppm) were adjusted accordingly at $7.26 \mathrm{ppm}$. Coupling constants (J) were measured in HertZ (Hz). Infrared (1R) spectroscopy was recorded by Agilent Technologies ATR-FT 5500 series FTIR instrument with 32 scans and frequencies are reported in $\mathrm{cm}^{-1}$. Melting points (Mp) were determined with a SMPI stuart Scientific melting point apparatus. Column chromatography was performed on silica gel $60 \mathrm{H}$, 200-400 mesh. Thin layer chromatography (TLC) was performed on pre-coated aluminum backed (silicycle), Tlc plate silica gel $(0.2$ 
$\mathrm{mm}$ ) and Visualized by spraying with concentrated sulfuric acid and then heated to $105^{\circ} \mathrm{C}$

\section{Sample Extraction}

Pulverized Acanthus montanus leaves (1 kg) was sequentially extracted using Soxhlet (n-hexane and ethyl acetate). Excess solvent was removed under reduced pressure and residue stored in the refrigerator. The ethyl acetate extract was dissolved in n-hexane and chloroform (1:1), and refluxed for three hours then filtered.

\section{Plant Collection and Extraction}

Fresh leaves of $A$. montanus were collected from their natural habitat in Egor Local Government Area of Edo State, Nigeria. The plant was identified by Dr. E.I. Aigbokhan, a taxonomist in the Department of Plant Biology and Biotechnology, University of Benin, Benin City. The leaves were washed with caution and air-dried in the laboratory for four weeks and pulverized to a fine powder. Four hundred and twenty grammes $(420 \mathrm{~g})$ of the sample was extracted with hexane and 99.5\% methanol (NDH, England) in a soxhlet extractor for 8 hours using $50 \mathrm{~g}$ at each batch. Excess solvent was removed under reduced pressure and residue stored in the refrigerator.

\section{Extraction and Isolation}

The dried leaves $(800 \mathrm{~g})$ were exhaustively extracted with hexane and methanol successively [13]. The methanol extract was concentrated on a rotary-evaporator and this extract was dissolved in methanol. Further, it was kept at $4^{\circ} \mathrm{C}$ for 72 hours. A light brown solid separated out which was filtered and collected and was then vacuum dried. The solid obtained was then applied to vacuum liquid chromatography on a silica column using hexane $\left(60^{\circ}-80^{\circ} \mathrm{C}\right)$, chloroform, ethyl alcetate, methanol and methanol water in the ratio of 2:1 [14]. The elutes were collected in a number of test tubes and monitored using TLC [15]. The elutes of similar retention factor (Rf) were then combined and evaporated. One of the fractions was used for further characterization. The isolated fraction was washed with $\mathrm{n}$-heptane to give compound 'Am2'. The TLC was done over silica gel $\left(\mathrm{GF}_{254}\right)$ using hexane-ethyl acetate (30:70) as developing solvent. The Rf was found to be 0.60 . The compound was observed as a white powder, m.pt $273.5^{\circ} \mathrm{C}$ (corrected). A yield of $8 \mathrm{mg}$ was obtained.

A small amount of solid 'Am3' glucoside was hydrolyzed using the method described in [16-17] by adding $8 \mathrm{mg}$ of glucoside to a mixture of amyl alcohol $(3 \mathrm{~mL})$, dilute hydrochloric acid $(4 \mathrm{~mL})$ and methanol $(25 \mathrm{~mL})$. The resulting solution was refluxed for about 6 hours and the refluxed solution was concentrated to about $10 \mathrm{~mL}$. To the concentrated solution, ethyl acetate was added in order to extract the sitosterol. The resulting organic solution was washed with water and dried over anhydrous sodium sulphate and evaporated under reduced pressure to obtain a white solid substance product which was recrystallized in methanol.

\section{Spectroscopic Characterization}

Different spectroscopic methods were used to elucidate the structure of the compound. The infrared spectrum was recorded on Shimadzu $1 \mathrm{~S}$ affinity. The nuclear magnetic resonance $\left({ }^{1} \mathrm{H}\right.$ NMR and $\left.{ }^{13} \mathrm{C} N M R\right)$ spectra were recorded on Bruker R-32 (500-MHz) in a deuterated solvent $\mathrm{CD}_{3} \mathrm{OD}$ and $\mathrm{CDCl}_{3}$ with tetra methyl silane (TMS) as standard. These are complemented with UVand MS.

\section{Animals}

Non-pregnant female albino rats were obtained from the animal house of the Department of Pharmacology and Toxicology, Faculty of Pharmacy, University of Benin. The animals were kept under standard environmental conditions with free access to standard rat feeds (Broiler mash) and water for a period of two weeks for them to acclimatise. The animals were handled according to standard guidelines for the use and care for experimental animals.

\section{Salt Solution (De-Jalon)}

$\mathrm{NaCl}(45.0 \mathrm{~g}), \mathrm{KCl}(2.10 \mathrm{~g}), \mathrm{NaHCO}_{3}(2.50 \mathrm{~g})$ and D-glucose $(2.50 \mathrm{~g})$ were weighed and made into a solution of $3.5 \mathrm{~L}$ distilled water. Calcium chloride $(0.40 \mathrm{~g})$ was made into a solution of $1.5 \mathrm{~L}$ distilled 
water in a separate beaker. Both solutions were then combined to give $5 \mathrm{~L}$.

\section{Uterine Muscles Contractile Activity Screening}

Female non-pregnant albino rats were pretreated intraperitoneally with $0.2 \mathrm{mg} / \mathrm{kg}$ of diethyl/stilbestrol $24 \mathrm{~h}$ prior to the determination of the contractile activity [23]. The rats were sacrificed under chloroform anaesthesia. The abdomen was opened and the two horns of the uterus carefully isolated, freed of mesenteric fat and a $1 \mathrm{~cm}$ piece was mounted in a $10 \mathrm{~mL}$ organ bath containing De-Jalon physiological salt solution. The tissue was bubbled with air using an aerator at temperature $37^{\circ} \mathrm{C}$ and $\mathrm{pH}$ of 7.4 . The spontaneous contraction of the uterus was recorded with 7003-B transducer connected to an Ugo Basile Data capsule calibrated channel recorder (model: 4050). The transducer was previously calibrated to establish a relationship between the force applied to the transducer and the gauge deflection (500 $\mathrm{mg}$ ). The tissue was allowed to equilibrate for $30 \mathrm{~min}$ before the start of the experiment and placed under tension of $500 \mathrm{mg}$. The concentration-response curves of oxytocin and acetylcholine induced contractions were first obtained and this concentration response curves each were repeated in the presence of the extract $(0.1,0.2,0.4$ aliphatic $-\mathrm{CH}$ stretching of $\mathrm{CH}_{3}$ and $\mathrm{CH}_{2}$ groups [20]. A band observed at $1095 \mathrm{~cm}-1$ was assigned to $\mathrm{C}-\mathrm{O}-\mathrm{C}$ linkage. The weak absorption observed at $1664 \mathrm{~cm}^{-1}$ was assigned to $(\mathrm{C}=\mathrm{C})$ stretching and $0.8 \mathrm{mg} / \mathrm{ml}$ ) to investigate its effect. The effect of the extract was compared to two positive controls (salbutamol and atropine) for oxytocin and acetylcholine concentration response curves respectively.

\section{Results and Discussion}

The results of the spectroscopic characterization and antimicrobial activities of stigmasterol and $\beta$-sitosterol from $A$. montanus leaves are reported in Table 1.

\section{Characterization of Compound Am2 as a Mixture of Stigmasterol} and $\beta$-Sitosterol

Compound Am2 was obtained as a white crystalline solid. Analysis of the ${ }^{1} \mathrm{HNMR}$ spectrum of the fraction showed a mixture of two compounds. The spectrum indicated signals characteristic to sterols, such as olefinic hydrogens. It showed a positive liberman burchard test with the formation of violet ring indicating a steroid skeleton. The ultraviolet (UV) maximum value of compound Am2was observed at $256 \mathrm{~nm}$ [18] (Table 1). The IR spectrum of compound Am2 showed broad band in the region $3420 \mathrm{~cm}^{-1}$, thus indicating the presence of $\mathrm{OH}$ of glucoside linkage [19]. The absorption observed at 2958- 2820
$\mathrm{cm}^{-1}$ was assigned
to asymmetric

(Table 2 and figure 2). Besides these, another three bands at 1452, 1379 and $836 \mathrm{~cm}^{-1}$ were observed. These observed values are in good agreement with the reported literature [21\} 
Table $1{ }^{1} \mathrm{HNMR}$ and ${ }^{13} \mathrm{C}$ NMR chemical shifts for Am3

\begin{tabular}{ll}
\hline $\begin{array}{l}\text { Spectroscopic } \\
\text { technique }\end{array}$ & Data \\
\hline $\begin{array}{l}\text { Mp } \\
\text { Rf } \\
\text { IR }\left(\mathbf{c m}^{-1}\right)\end{array}$ & \\
${ }_{\mathbf{1 3}} \mathbf{C ~ N M R}$ & $3420,2928.90,288.10,1641.80$ \\
& $36.79(\mathrm{C}-1), 29.23(\mathrm{C}-2), 76.85(\mathrm{C}-3), 39.28(\mathrm{C}-4), 140.41(\mathrm{C}-5), 121.20(\mathrm{C} 6), 31.38(\mathrm{C}-$ \\
& $7), 31.26(\mathrm{C}-8), 49.55(\mathrm{C}-9), 36.18(\mathrm{C}-10), 20.56(\mathrm{C} 11), 38.26(\mathrm{C}-12), 41.82(\mathrm{C}-$ \\
& $13), 56.13(\mathrm{C}-14), 23.83(\mathrm{C} 15), 27.76(\mathrm{C}-16), 55.38(\mathrm{C} 17), 11.64(\mathrm{C}-18), 19.07(\mathrm{C}-$ \\
& $19), 35.45(\mathrm{C}-20), 18.58(\mathrm{C}-21), 33.29(\mathrm{C}-22), 25.36(\mathrm{C}-23), 45.09(\mathrm{C}-24), 28.64(\mathrm{C}-$ \\
& $25), 19.690 .87(\mathrm{C}-26), 18.89(\mathrm{C}-27), 22.06(\mathrm{C}-28), 11.75(\mathrm{C}-29), 100.73(\mathrm{C}-$ \\
& $30), 73.42(\mathrm{C}-31), 76.86(\mathrm{C}-32), 70.04(\mathrm{C}-33), 76.72(\mathrm{C}-34), 62.82(\mathrm{C}-35)$. \\
& $1.0(\mathrm{~m}), 1.40(\mathrm{~m}), 1.51,1.26(\mathrm{~m}), 8(\mathrm{~m}), 2.98(\mathrm{~m}), 2.26(\mathrm{~m}), 1.988(\mathrm{ddd}), 5.35(\mathrm{~m}), 1.95(\mathrm{ddd}$, \\
& $=16.0,2.5,7.0) 1.36(\mathrm{~m}), 0.85(\mathrm{~m}), 1.42(\mathrm{~m}), 1.42(\mathrm{~m}), 1.52(\mathrm{dd}), 0.95(\mathrm{~m}), 1.05(\mathrm{~m}), 1.57(\mathrm{~m})$ \\
& $, 1.25(\mathrm{~m}), 1.85(\mathrm{~m}), 1.20(\mathrm{~m}), 0.70(\mathrm{~s}), 0.94(\mathrm{~s}), 1.40(\mathrm{~m}), 0.95(\mathrm{~d}$, \\
& $\mathrm{J}=6.5), 1.20(\mathrm{~m}), 1.25(\mathrm{~m}), 0.94(\mathrm{~m}), 1.68(\mathrm{~m}), 0.87(\mathrm{~d}, \mathrm{~J}=6.5), 0.88(\mathrm{~d}, \mathrm{~J}=7.0), 0.97(\mathrm{t}$, \\
& $\mathrm{J}=7.5), 0.97(\mathrm{t}, \mathrm{J}=7.5), 4.20(\mathrm{~d}, \mathrm{~J}=7.9), 4.40(\mathrm{~m}), 3.27(\mathrm{dt}, 8.0, \mathrm{~J}=4.5,8.0), 3.40(\mathrm{~d}, \mathrm{~J}=4.5), 3.6$ \\
& $0(\mathrm{t}, \mathrm{J}=4.5) 4.55(\mathrm{dd}, \mathrm{J}=2.5,11.7)$ \\
\hline
\end{tabular}


${ }^{1} \mathrm{H}$ NMR spectrum of compound Am2 showed a chemical shift in the range $0.87-0.97 \mathrm{ppm}$, thus

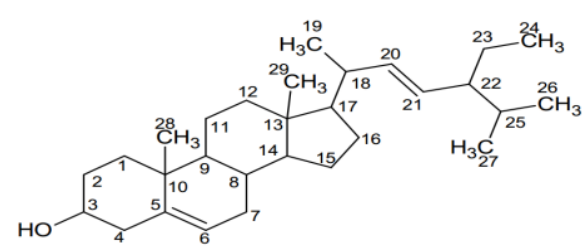

Compound 1: Stigmastero

A singlet observed at $0.70 \mathrm{ppm}$ was assigned to methyl protons (H-18). The proton attached to olefinic linkage was observed at $5.35 \mathrm{ppm}$. The signals observed at 0.87 and $0.88 \mathrm{ppm}$ were assigned to methyl protons of isopropenyl moiety. Methyl proton (H-21) were observed at $0.95 \mathrm{ppm}$ with coupling constant $\mathrm{J}=6.5 \mathrm{~Hz}$. The proton of glucose was observed at $2.89-4.27 \mathrm{ppm}$ as a multiplet. The proton of $-\mathrm{CH}$ group of glycoside was observed at $4.20 \mathrm{ppm}$. H-3 proton was observed at $2.98 \mathrm{ppm}$. The hydroxyl protons of sugar moiety (Table 1) showed resonance at 3.56-3.60 $\mathrm{ppm}(\mathrm{J}=4.5$ $\mathrm{Hz}$ ) and were assigned to C-2', C-3' C-4' and C-6'respectively [22]. All these hydroxyl signals disappeared on shaking with $\mathrm{D}_{2} \mathrm{O}$. The ${ }^{13} \mathrm{C}$ NMR spectrum of compound Am3 indicated 35 carbon signals, of which six were for the sugar moiety and 29 were attributed to the aglycone moiety. The carbon signals of the sugar moiety observed at 62.82 (C-6'), 70.04 (C-4'), 73.42 (C-2'), 76.72 (C-5'), $76.86\left(\mathrm{C}^{\prime} 3^{\prime}\right)$, and 100.73 (C-1') ppm were well consistent with those of glucose moiety. The aglycone moiety signals were observed at 140.41 (C-5), 121.20 (C-6), 76.85 (C-3), 56.13 (C-14), 55.38 (C-17), 49.55 (C-9), 45.09 (C-24), 41.82 (C-13), 39.28 (C-4), 38.26 (C-12), 36.79 (C-1), 36.18 (C-10), 35.45 (C-20), 33.29 (C-22), 31.38 (C-7), 31.26 (C-8), 29.23 (C-2), 28.64 (C-25), 27.76 (C-16), 25.36 (C-23), 23.83 (C-15), 22.06 (C-28), 20.56 (C-11), 19.69 (C-26), 19.07 (C-19), 18.89 (C-27), 18.58 (C-21), 11.75 (C-29) and 11.64 (C-18) ppm [23]. These data confirmed that compound Am3 is $\beta$ - suggesting the presence of methyl protons $(12 \mathrm{H}$, H-21, 26, 27, 29).

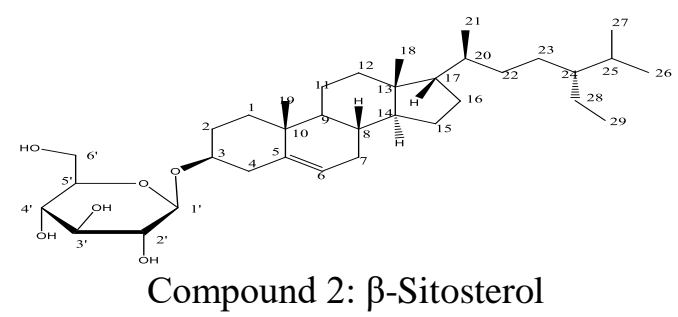

sitosterol-3-O- $\beta$-D-glucoside (Fig. 1). The chemical shift at 19.69 and 18.89 ppm were assigned to two methyl group. The signals observed at downfield 11.64, 19.07, and $18.58 \mathrm{ppm}$ were assigned to angular methyl group moiety linked at C-18, C-19 and C-21. The signals at $140.41,36.18$ and $41.82 \mathrm{ppm}$ were assigned to the quaternary carbon at point C-5, C-10 and C-13. The signals observed at 31.26, 49.55 and 56.13ppm were assigned to protons at C-8, C-9 and C-14, respectively. The upfield chemical shift at $36.79,29.23,39.28,31.38,49.55,20.56$, $38.26,56.13,23.83,27.76$ and $55.38 \mathrm{ppm}$ were assigned to cyclohexyl and cylopentyl of $\mathrm{A}, \mathrm{B}, \mathrm{C}$ and $\mathrm{D}$ rings. The carbon of cyclic linkage part joint to the side chain was observed at $35.45 \mathrm{ppm}$. Anomeric carbon 100.73 (C-1') and that of proton (H-1') at 4.20 with $76.85 \mathrm{ppm}$, respectively, confirmed the glucose moiety at 3 positions which are given in (Table 3, figures 4 and 5). Stigmasterol and sitosterol are phytosterol commonly found in the plant kingdom. They are obtained in mixture of hard separation, because they show similar physical properties. While stigmasterol has double bond at $\mathrm{C}-22$ and $\mathrm{C}-23$, sitosterol has a single bond. Hence it is difficult to obtain sitosterol in pure state [12]. In 1H NMR spectrum, mixture containing stigmasterol are identified by signals referent to the vinyl, hydrogens ( $\mathrm{H}-22$ and $\mathrm{H}-23)$ that show up as two doublets between $\mathrm{H} 4.17$ and $H$ 5.35. sitosterol has its usefulness in the treatment of immune dysfunctions, inflammatory disorders and rheumatoid arthritis breast cancer, colon cancer and 
benign prostatic hypertrophy [13]. Antioxidant, anti-inflammatory, analgesic and anthelmintic activities, Its hypoglycemic and hypercholesterolemic property as well as its usage as precursor in the synthesis of steroidal drugs has been reported [14].

\section{Uterine Effect}

The results of the effect of methanol extract of Acanthus montanus on oxytocin and acetylcholine induced contraction in the nonpregnant rat uterus are shown on Figs. 1 and 2.
The results showed that various concentrations of oxytocin and acetylcholine produced a significant contraction of the rat uterus. Administration of the extract produced a significant $(P<0 \quad .05)$ dosedependent reduction in oxytocin and acetylcholine induced contractions by the extract at concentration tested (Figs. 1-2). From the graphical plot, the percentage response to log dose of Acanthus montanus extracts supplemented with oxytocin exhibited anti-contractile effect of the uterus of rats at $30 \%:-2.699,40 \%:-2.398$ and $45 \%$ : -2.097 (Fig. 1).

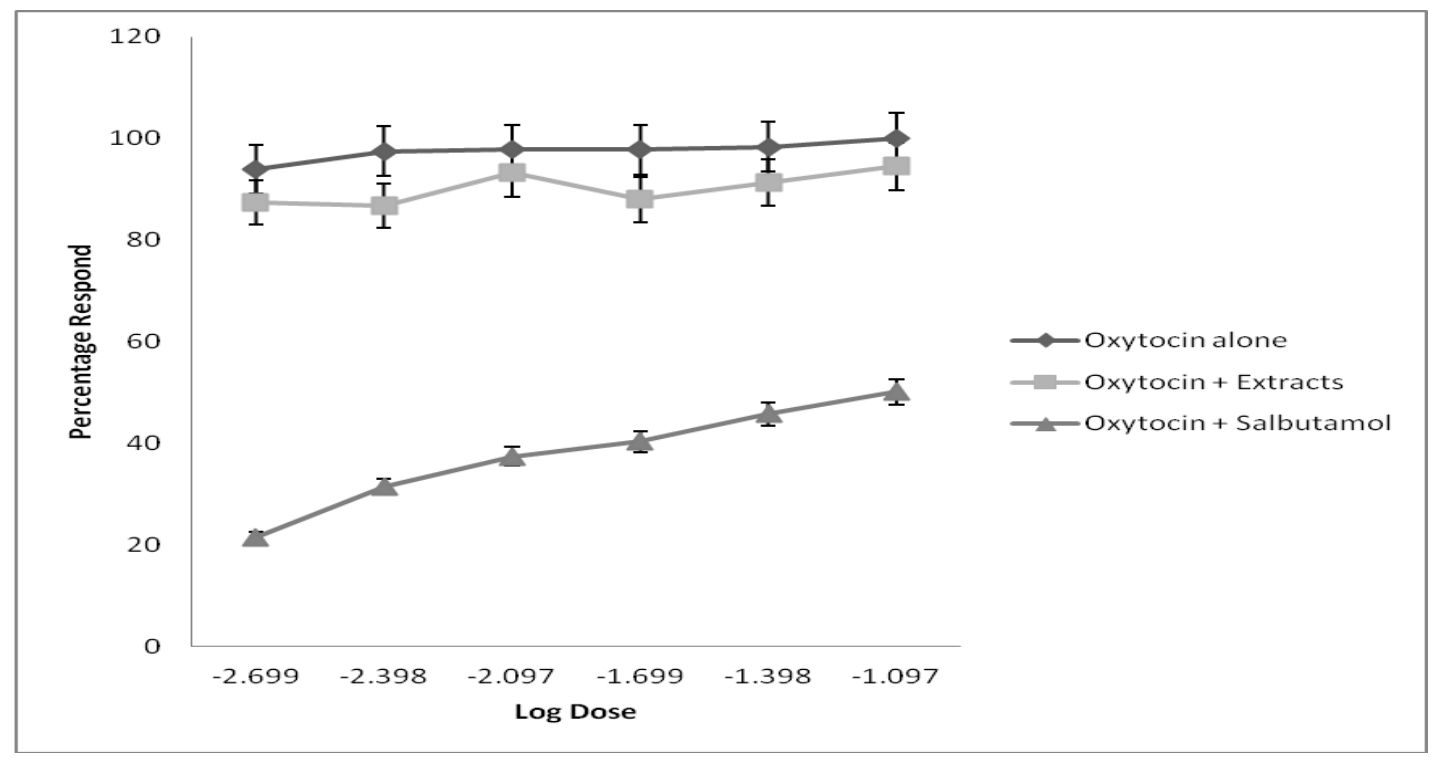

Fig. 1. Effects of the methanol extract of Acanthus montanus on oxytocin induced contraction in the non-pregnant rat uterus

Values are mean percentage response $\pm S E M(n=5$ per group). $* P 0=.05$ significantly different from oxytocin induced contraction alone.

OXY: Oxytocin alone, OXY+extract :Oxytocin and $0.1 \mathrm{~m} / 100 \mathrm{mg} / \mathrm{ml}$ of Acanthus montanus OXY+Sal: Oxytocin and 5 $\mu$ g of Salbutamol

while for acetylcholine induced contraction, the effect of anti contractile activity was observed at 25\%: $-0.699,40 \%$ : $-0.398,45 \%$ : -0.097 and 45\%: 0.301(Fig. 2). This study revealed that extract at both doses produced significant inhibition of oxytocin and acetylcholine induced contractions of the uterine smooth muscle in non-pregnant rats. The work of Newal [28] indicated also that the effect on acetylcholine induced contractions may be due to muscarinic receptor blockade. These results also indicate a shift of the concentration response curve to the right produced by both doses of the extracts [29 and 30]. 


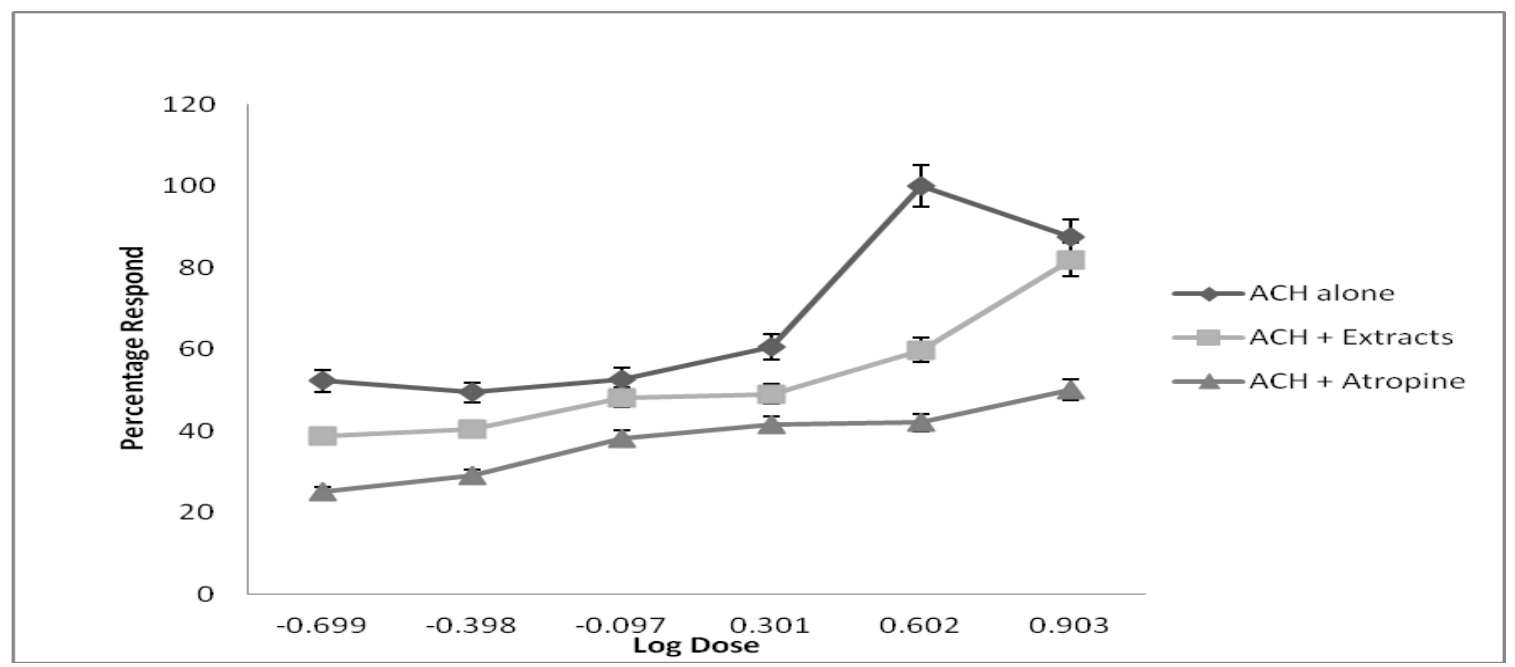

Fig. 2. Effects of the methanol extract of Acanthus montanus on acetylcholine induced contraction in the non-pregnant rat uterus

Values are mean percentage response $\pm S E M(n=5$ per group). $* P<.05$ significantly different from acetylcholine induced contraction alone.

ACH: acetylcholine alone

$\mathrm{ACH}+$ extrtact: acetylcholine and $0.1 \mathrm{~m} / 100 \mathrm{mg} / \mathrm{ml}$ of Acanthus montanus

$\mathrm{ACH}+$ Atr: Acetylcholine and $5 \mu \mathrm{g}$ of Atropine.

\section{References}

1. L.L. Schiebinger (2004). Plants and empire: Colonial bio prospecting in the Atlantic world. Harvard University Press: Cambridge, Mass.; 4 .

2. E.J. Adjanohoun, L. Ake Assi, A. Ahmed, J. Eyme, S. Guindo, A. Kayonga, A. Keita and M. Lebras (1988). Médecine traditionnelle et Pharmacopée. Contribution aux études botaniques et floristiquesau Comores. Rapport Agence de Coopération Culturelle et Technique, Paris. 1988;243.

3. Mendonça de Carvalho LMM. The symbolic uses of plants pages: In E. N. Anderso, D.M. Pearsall, E. S. Hunn and N. J. Turner eds. Ethnobiology. Wiley-Blackwell, New York. (2011); 353-371.

4. P. Gazzerro, M.C. Proto, G. Gangemi, A.M. Malfitano, E. Pisanti and S. Ciaglia, (2012). Pharmacological actions of statins: A critical appraisal in the management of cancer. Pharmacological Reviews; vol. 64:102-146.

5. V. Piironen, D. Lindsay, T. A. Miettinen ., J. Toivo and A.M. Lampi (2000). Plant sterols:
Biosynthesis, biological function and their importance to human nutrition. J Sci Food Agric; vol. 80:939-966.

6. T. Griebel and J. Zeier (2010). A role for beta-sitosterol to stigmasterol conversion in plantpathogen interactions. Plant Journal; vol. 63(2):254-268.

7. S. Saeidnia, A. Manayi, A.R. Gohari. and M. Abdollahi (2014). The story of beta-sitosterol- A review. European Journal Med Plants. Vol. 4(5): 590-609.

8. Food and Drug Administration (FDA) (2010); Department of Health and Human Services, Food labeling; health claim; phytosterols and risk of coronary heart disease. Federal Register. Vol. 75:76536- 76571.

9. S.L. Gerlach, R. Rathinakumar, G. Chakravarty, U. Göransson, W.C. Wimley and S.P. Darwin (2010) Anticancer and chemosensitizing abilities of cycloviolacin 02 from Viola odorata and psylecyclotides from Psychotria ptothyrsa. Biopolymers; vol. 94(5):617-625.

10. T. Lou, W. Jiang, D. Xu, T. Chen and Y. Fu, (2015). Inhibitory Effects of Polydatin on 
Lipopolysaccharide-Stimulated RAW 264.7 Cells. Inflammation; vol. 38(3): 1213-1220.

11. C.A. Kontogiorgis, E.M. Bompou, M. Ntella and W.V. Berghe (2010) . Natural products from mediterranean diet: From anti-inflammatory agents to dietary epigenetic modulators. Antiinflamm Anti-allergy Agents Med Chem.vol. 9(2):101-124

12. S.S. Gautam, S. Navneet and S Kumar (2012). The antibacterial and phytochemical aspects of Viola odorata linn. extracts against respiratory tract pathogens. Proc Natl Acad Sci, India B Biol. Sci.vol. 82(4):567-572.

13. J.B. Harborne (1998), Phytochemical methods: A guide to modern techniques of plant analysis. 3rd Edition, Chapman and Hall, London;

14. N.J. Morris and L.S. Lee(1961). Peanut flour constituents, Isolation and Identification of a sterol glucoside from peanut flour. Journal of Agricutural and Food Chemistry. vol. 9(5):401403.15. Stahl E.

15. Thin layer chromatography: A laboratory handbook. 2nd Edition, Springer. New York; (1969).

16. U.U. Pateh, A.K. Haruna, M. Garba, I. Iliya, I.M. Sule, M.S. Abubakar and A.A. Ambi (2009); Isolation of stigmasterol, $\beta$-sitosterol and 2 hydroxyhexadecanoic acid methyl ester from the rhizomes of Stylochiton lancifolius Pyer and Kotchy Araceae), Nigerian Journal of Pharmaceutical Science.Vol. 8(1):19-25.

17. R. Pandey, R.K. Verma and M.M. Gupta (2006); Pentadecanoic acid $\beta$-D-glucoside from Clerodendrum inerme. International Journal of Chemistry, 45B:2161-2163.

18. N.J. Morris and L.S. Lee (1961). Peanut flour constituents, Isolation and Identification of a sterol glucoside from peanut flour. J Agric Food Chem.; vol. 9(5):401-403.15.

19. M. Arora and A.N. Kalia(2013), Isolation and characterization of stigmasterol and $\beta$ sitosterol-D-glycoside from thanolic extract of the stems of Salvadora persica Linn. International Journal of Pharmaceutical Science; vol. 5:245-249.

20. C.N. Rao, Chemical applications of infrared spectroscopy. Academic Press, New York; (1963).
21. A. EI-Fishawy, R. Zayed and S. Afifi (2011), Phytochemical and pharmacological studies of Ficus auriculata Lour. Journal of Natural Products. Vol. 4:184-195.

22. K.H. Lee, Y.D. Min, S.Z. Choi, H.C. Kwon, O.R. Cho and K.C. Lee (2004). A new sesquiterpene lactone from Artemisia rubripesnakai. Arch Pharmaceutical Researches,vol. ; 27:1016-1019.

23. V.S.P. Chaturvedula, I. Prakash(2012), Isolation of Stigmasterol and $\beta$-Sitosterol from the dichloromethane extract of Rubus suavissimus. International Current Pharmaceutical Journal, vol. 1(9):239-242.

24. T. and H.K $\operatorname{Kar}(2014)$, Isolation and Characterization of $\beta$-Sitosterol-3-O- $\beta$-Dglucoside from the Extract of the Flowers of Viola odorata Peshin; Biological Journal of Pharmaceutical Research,vol. 16(4):1-8.

25. M.R. Habib, F. Nikkon, M. Rahman, M.E. Haque and M.R. Karim (2007). Isolation of stigmasterol and beta sitosterol from methanolic extract of root bark of Calotropis gigantean. Journal of Biological Sciences. Vol.;10: 41744177.

26. M.S Butler (2004). The role of natural products chemistry in drug discovery. Journal of Natural Products. vol. 67(12):2141-2153.

27. A. Mann, A. Yusuf, S. Daniyan (2015). TLC analysis and bioactivity screening of the stem bark extract of Anogeissus leiocarpus against multi-resistant Staphylococcus aureus and quantification of its phytoconstituents. A Research Journal of Pharmaceutical, Biological and Chemical Sciences. Vol. 5(2):187-203.

28. C.N. Raob(1963). Chemical applications of infrared spectroscopy. Academic Press. New York;

29. A. EI-Fishawy, R. Zayed, S. Afifi(2011). Phytochemical and pharmacological studies of Ficus auriculata Lour. J of Nat Prod.; 4:184195.

30. C.A. Newal, L.A. Anderson and J.D. Phillipson (1986). Herbal medicine, a guide for health care professionals. Pharmaceutical press. 291-296. 